\title{
A Literature Study on Family Business Management from 1990 To 2012
}

\author{
${ }^{1}$ Mohd abass bhat, ${ }^{2}$ Javeed Ahmad Shah , ${ }^{3}$ Aijaz Ahmad Baba \\ ${ }^{I}$ Department of Business and Financial Studies, University of Kashmir. Hazratbal Srinagar Kashmir (J\&K) \\ India. \\ ${ }^{2}$ Research scholar, Dept. Pt. Jawarlal Nehru, Institute of Business Management Vikram University, Ujjain \\ (M.P). \\ ${ }^{3}$ Lecturer Commerce, Govt. B. Hr. Sec. School Unisoo, kupwara. (J\&K) India
}

\begin{abstract}
Economic liberalization and rapid expansion after 1990 leads to an industrial base in recent years have not only created growth opportunities for many but also have tested their resource capabilities to respond to them; some have chosen to follow the role of a custodian of their existing wealth and followed the preservation route, while some others have followed more of an entrepreneurial route of exploiting opportunities with or without relevant resources, with mixed results. One of the key resources for all of them is their family, and their prime concern is wealth and welfare of their family. A major dilemma many of them have faced particularly in the last two decade since economic liberalization began is to choose between combinations of risks and returns of business growth and conservation of wealth of the family. Family as a social institution is one of the oldest surviving (Goode, 1982), but only in recent years family business, an important arm of it started receiving academic attention. This article reviews the literature on family business management In general; this literature is dominated by descriptive articles that typically focus on family relationships. However, the literature does not usually address how these relationships affect the performance of a family business. We also identify some of the key issues and gaps that should be explored in future studies if research is to contribute to improving the management practices and performance of family firms
\end{abstract}

\section{Introduction}

Family business is a vibrant area of growing interest today among research theories investors policymakers , and many others with good cause .Recent research has demonstrated that family firms are top performs . whether measured by the bottom line, value creation by the shareholder or their capacity to create job ,family companies out perform their normal non family counterparts. The turbulence brought about by global hyper-competition too, has created an increasing awareness that speed ,sustainability, flexibility ,quality of product and service, brand, customers relationship, employees care, and patient capital are genuine sources of competitive advantage . these advantages are often pursued via idiosyncratic business strategies developed by firm that are family controlled family business to be sure, confront substantial challenges but they also often posses unique advantages born out of unique and dynamic family business interaction (poza,2010) A detailed review of definition employed in studies reveals that there is no clear demarcation between and non family business and that no single definition can capture the distinction between the two types of entities

Family business has been defined as a business that is owned and managed (i.e, controlled) by one or more family members (handlers ,1989.,Hollander \& Elman ,1988).A more detailed definition is provided by Davis and Tagiuri (1982).they define family firms as: „, organization where two or more extended family members influence the direction of the business through the exercise of kinship ties ,management roles, or ownership rights .,,moreover Gallo(1944) has asserted that family are essentially the same in every country in the world relative to their problems ,issues and interests.

A business is a family business when it is an enterprise growing out of the family's needs ,built on the family's abilities worked by its hands and guided by its moral and spiritual values, when it is sustained by family commitment, and passed down to its sons and daughter as a legacy as precious as the family's nature (Astrachan et al,2005) although many small and small micro business are family-owned and operated, there is evidence that family firms are also fast growth firms are also fast growth firms are also fast growth firms and very large successful firms .

Families are vital and supportive environment for entrepreneurial behavior. entrepreneurship research has revealed that family support and the presence of self-employed parents are important influence in venture initiation and business ownership (Shapero and sokol; 1982 copper ,1986 .sexton and bowman-Upton(1991) define an entrepreneur as,, one who can recognize an opportunity in the marketplace and is willing to marshall the resources necessary to exploit that opportunity for long term personal gain ,, entrepreneurship is the start and heart of most family business and the phenomenon of an, entrepreneurial family, fosters ,subsidize and 
enhance the efforts of its members who engaged in entrepreneurship . in fact the family business is quite simply the ,wider-lens, view of entrepreneurship as the initial business efforts of one or more family members grows and changes overtime.

Research estimates that at least $90 \%$ of the business in the united states are family owned and controlled (Ibrahim \& Ellis) and contributed somewhere between 30 and 60 percent of the nation,s gross domestic product (GDP) and half of total wages paid (Glueck \& Meson, 1980; Ibrahim \& Ellis ,1994; ward ,1987 Dreux (1990) concludes that the family business universe approaches and possibly exceeds the entire publicly owned universe in size and scope of economic activity .He characterizes family firms as a "parallel economy"

The economic value provided by family firms is enhanced by their tendency toward long term strategic rather than a need for quarterly results , an aversion to debt, and their inclination to reinvest dividends (Gallo,1994).A number of studies have shown that family firms outperform their industry groups and their non family counterparts. In 1969, Monsen found that family business net income to net worth ratio was $75 \%$ higher than manager-controlled firms. He concluded that family provide a greater return on investment ,have a bettermanaged capital structure and more efficient allocation of resources. Jaffe (1990)states that a 1986 study by US News and World Report found that of the 47 largest family ,31 outer performed the Dow-Jones Index. Fast growth family firms are being recognized by companies such as Ernst and Young who award, in Texas, the Ernst and Young Fastest Growing Family Award (Genusa, 1994).The family firm that won in 1994 demonstrated a $6000 \%$ growth rate.

In a recent review of the state of family business worldwide, the sheer number of family firms around the world can leave no doubt as to their predominance, and therefore their economic importance and significance .In Germany, $75 \%$ of the work forces are employed by family businesses, who contribute $66 \%$ of the GDP .Redial (1994)categorizes $80 \%$ (about two million companies )of all Germany companies as family controlled and concludes that they are the "backbone "of the German economy .In Australia ,Owens (1994) estimates that $75 \%$ of Australia

Businesses are family owned and controlled, and that they account for $50 \%$ of the country workforce .In Chile, Martinez (1994) concludes that family firms contribute greatly to Chile s GDP and controlled. Chile is currently the most dramatic example of economic growth in all of Latin America, so the effect of family businesses on the economy there is a particularly positive one, given a recent finding that $65 \%$ of medium to large sized enterprises are family owned .The statistics are similar in other regions (Gallo, 1994);in Mexico 80\% are family businesses and have been known to dominate the economy there for over 100 years. In Spain, it is known that for companies with over $\$ 2$ million in annual sales, family firms account for $71 \%$ and that $17 \%$ of the top 100 Spanish firms are family businesses. In the United Kingdom, 76\% of the top 8000 companies are family owned and controlled, with higher proportions expected in the wider business population "Across Western Europe, between $45 \%$ and $65 \%$ of the GNP and employment are contributed by family businesses. The lowest level of family business activity is in Portugal and the highest in Italy, where $99 \%$ of firms are run by families."(Gallo, 1994, pp.47-49)

Family- owned businesses exist all over the world and some of the worlds oldest firms are family owned e.g.Kongo Gumi of Japan was founded in $578 \mathrm{AD}$ and is currently managed by the $30^{\text {th }}$ generation. Some of the largest wealth creators and businesses are family owned like wal-Mart.

As per Buuren (2009) Family businesses world-wide are contributing increasingly to the economic activity in their perspective countries . Table 1.5 provides an overview of the economic contributions and proportions of family businesses to total businesses, world-wide. As it is indicated in Table 1.5, about $96 \%$ of businesses in the USA are family businesses, while in that country these businesses contribute as much as $40 \%$ to the GNP (Timmons and Spinelli, 2007)

In south Africa it is estimated that more than $80 \%$ of all businesses have family ownership involvement and more than $60 \%$ of all listed companies in south Africa comprises family involvement at least during its start -up phase (Dickinson, 2000; Venter, 2002).However, a large proportion of family businesses in south Africa are small to medium size enterprises, with nearly 50\%employing less than 20 people per business (Maas, 1999).

In India also, the highest generator and creator of wealth are family owned businesses India has seen some very influential families in business. These families have made a lot of difference in the business and industrial culture of the country. These families have existed for over hundred year and have influenced the economic and political situation of the country.

Until the government of India took a very socialist stand on investment the family-owned businesses in India were very successful and Tata Airline was among the top 10 Airlines in the world. The economy of the country was gauged for several years on the basis of the growth and development of the family business. In the 1970 private owned firms $93 \%$ of which were family -owned at that time, were put through very regressive policies to control growth of private wealth. It was felt that the family -owned business and family-owned business houses would lose their place in the industrial map of the country. 
Table 1.5 Worldwide Highlights of Family Businesses

\begin{tabular}{|l|l|l|l|}
\hline S.No & Country & \%of FBs & GNP \\
\hline 1 & Brazil & $90 \%$ & $63 \%$ \\
\hline 2 & Chile & $75 \%$ & $50-70 \%$ \\
\hline 3 & USA & $96 \%$ & $40 \%$ \\
\hline 4 & Belgium & $70 \%$ & $55 \%$ \\
\hline 5 & Finland & $80 \%$ & $40-50 \%$ \\
\hline 6 & France & $>60 \%$ & $>60 \%$ \\
\hline 7 & Germany & $60 \%$ & $55 \%$ \\
\hline 8 & Italy & $93 \%$ & NA \\
\hline 9 & Netherland & $74 \%$ & $54 \%$ \\
\hline 10 & Poland & $80 \%$ & $35 \%$ \\
\hline 11 & Portugal & $70 \%$ & $60 \%$ \\
\hline 12 & Spain & $79 \%$ & NA \\
\hline 13 & Uk & $70 \%$ & NA \\
\hline 14 & Australia & $75 \%$ & $50 \%$ \\
\hline 15 & India & NA & $65 \%$ \\
\hline
\end{tabular}

Source: Timmons and spinell, 2007

Time has proved this to be wrong because the family-owned businesses have proved to be very strong in their determination to carry the business on. But there are several road blocks that have ensured that Indian familyowned firms are global leaders in their field.

Family firms lead more directly to self-sufficient people in healthy communities. Few will disagree that private enterprise is the "bricks and mortar" of any economy. The individual characteristics of entrepreneurs, their ethnic backgrounds, family culture and community involvement are the substratum on which the majority of businesses are built and managed. Depending on how successful transitions are in family-held firms from one generation to the next, these unique styles and values may not be transmitted throughout local and regional communities.

Family wealth and innovation remain a potent force in the development of socioeconomic systems. Nevertheless, undue focus has been placed on the plight of larger, typically publicly-held conglomerates .The media, sociologists and economists have until very recently, enterprises shape and are part. Considering the preponderance of family firms, focus on the family and the role of the family in the economy is but obvious.

As larger and larger numbers of family-held companies change hands from one generation to the next, more and more family legacies are lost due to poorly planned transition (ward, 1987).with new owners with different values taking over these firms, the impact is often negative, both in terms of company productivity and profitability, but also in terms of negative influence on families and communities. Astrachan (1988) has revealed through the examination of the impact of family firms undergoing a transfer of management that sensitivity to the existing culture of the firm and the local community is critical to the continued success of the business.

Working from both a sociological and economic perspective, Benedict (1968) observes how the family firm is more important in the initial rather than the later stages of an economic systems development .At the same time his conclusions suggest the continuing important of a family firms characteristics in a deteriorating or unstable system.

Just as families are the building blocks of a stable society, so are family businesses important in building a stable economy .A family enterprise is by its very nature more inclined than other types of corporations to reinvest in itself to support and perpetuate wealth in future generations. The family firm has the capacity to make long-term investment and resist the pressure of analysts for short-term returns which frequently burden the publicly held corporation.

Research into the dynamic of family firm will have important implications not only for private enterprise but also for the familial, societal and economic systems in which they are embedded.

The issues faced and the interests involved by family-owned businesses all over the world are more or less the same. The importance of the family in business and the blurredness of the distinction between business and family are predominant issues.

The family firm literature argues that family firms are different from nonfamily firms. Research indicates family companies are preferred by consumers and are more involved with customer service, offer greater opportunities for women, have a respect for tradition, and take care of their employees (Longennecker, Moore \& Schoen, 1989; Lyman, 1991; Prokesch, 1986). At the same, family firms are reported to have problems with joint decision-making, career choices and supervision of family members as employees, and succession issues, including tax burdens. 
Professionals' focused on family businesses include a wide array of academicians with varied disciplinary background including business, family economics, family sociology and psychology and practitioners including accountants, lawyer, financial officers, business consultants and family therapists.

There is a great demand for courses on family managed business in various countries across the world. In order to meet this demand several B-Schools in India are also now offering full time and part time Family Managed Business programs e.g. Narsee Monjee Institute of Management Studies, Mumbai; SP Jain Institute of Management \& Research, Mumbai2; Welingkar Institute of Management Development \& Research, Mumbai; and The Centre for Family Managed Business (CFMB), Mumbai3.

In United States, over 60 universities now have family business programs (Vinturella,Elstrott \& Galiano,1993) and a small group of programs exist as private non-university entities.Many of these university programs are associated with centers for Entrepreneurship. Schools such as Harvard University, Cornell University, Baylor University, university of Southern California, University of St.Louis, and the University of St. Thomas have held family business conferences, developed cases and state of the art curriculum, and participated in family business research consortiums

Due to this high importance of family firms, academia has finally recently begun to recognize their necessity as a research object (Chrisman et al.,2002) According to Dyer Jr. , 2003, the field of management studies has paid insufficient attention the family firms, unique theoretical and practical problems so far. The interest in family firm research has accordingly grown significantly in the recent years, leading to a distinctive legitimate and emerging field of study in business research. The underlying supposition there in is the question whether family firms do really behave differently from non family firms and if so, how and why they are different. Several researchers suggest that the family-form of organization holds essential advantage (Anderson et al; 2003;Moconaughy et al;1998)

Research on family firms remains a new field which trying to legitimacy within management studies (hoy, 2003).There is a dearth of research on family businesses and many aspects of such firms merit attention from both the businesses side and the family side. Although the importance of entrepreneurship and family businesses can be documented, the study of entrepreneurship as it matures into a family business and changes over time has only recently emerged. Such study is critically tied to the study of both the business and the family behind the business. The study of the family business can reveal new knowledge about business formation, growth and expansion, professionalizing, strategic management, and succession .From the business side, for example, we know very little about the difference of family firms between the large scale versus micro enterprises, and the dynamic of change over the life course of the family firm. Moreover, the growth rate of family firms, the problems of strategic.

\section{The Studies Related To Various Issues Of Family Business Research And Presented Below In Chronological Order, Starting From 1990 To 2012.}

Berenbeim (1990) has examined the findings of qualitative study of twenty large family businesses (above $\$ 100$ million) from the United States, Europe and Latin America. The study focuses on the family businesses that have successfully completed the transition from founder to professional management, and it identifies many of the emotional and managerial dilemmas that arise as companies move from one generation to next. The author outlines the specific steps these companies have taken in order to constructively manage successions and continuity.

Barney (1991) states that the organizational performance is one of the most important constructs in management research. He has reviewed the context that frames organizational performance as a dependent variable with specific emphases on how it is operationalzed and measured. The research contexts of the past studies are firmly anchored around a multidimensional conceptualization of organizational performance related predominantly to stakeholders, heterogeneous market circumstances, and time. The review of the operationalisation and measurement of performance highlights the limited effectiveness of commonly accepted measurement practices in tapping this multidimensionality. By synthesizing the literature, the foundations are laid for the improved measurement of performance in management research.

Dean (1992) states the findings from an investigation of business owned and managed by African and American families in the los angels' area. Its dual purposes are to identify salient characteristics and to explore commonly held assumptions about African American family businesses and their owner managers. Several widely held beliefs about African American family businesses were not supported.

Wong (1993) has examined the three aspects of Chinese economic feminism nepotism, paternal and family ownership. The article is mainly concerned with the last aspect and the resultant phenomenon of the prevalence of family firms among privately owned Chinese commercial and industrial enterprises. It is argued that such 
firms are not necessarily small, impermanent and conservative because tend to behave differently at various stages of their developmental cycle. Four phases of development- emergent, centralized, segmented and disintegrative- are identified and discussed. This Chinese pattern is then compared with its Filipino and Japanese counterparts.

Amit and schoemaker (1993) have explored the relationship between dynamic capabilities and firm performance. In particular the study addresses the questions of whether dynamic capabilities impact directly or indirectly on performance. Using data from manufacturing firms, the paper articulates and measures dynamic capabilities as a multi-dimensional construct with three underlying factors: coordination, learning and strategic competitive response. Then, structural equation modeling is employed to explore the relationships among dynamic capabilities, functional competences and firm's performance. Empirical findings suggest that dynamic capabilities are antecedents to functional competences which in turn have a significant effect on performance. Direct effects on performance are found to be insignificant. Furthermore, similar effects seem to hold for both higher and lower levels of environmental dynamics. Theoretical and practical implications are discussed.

Harris and ward (1994) state that title research has been conducted on family business strategy, even though a significant portion of the nation's largest companies and family controlled. This article provides a frame work for addressing strategy and proposes topics for research on family business strategy. Topics include mission, industry and situation analyses, global strategy, and strategy implementation.

Handler (1994) has examined the research of successions in the field of family business management. Five streams are highlighted: (1) succession of a process, (2) the role of the founder, (3) the perspective of the next generation, (4) multiple levels of analyses and (5) characteristics of effective successions. Gaps in the literature and future research directions are also presented.

Barnes (1994) has examined his field work of Harvard business school. Should a family business in the family? The question is really academic, since families appear to be in business to stay. But when the management moves from one generation to the next, the transition is often far from orderly. In addition, as the company develops, there is need for a management style that goes beyond survival thinking, and entrepreneurs tend not to be recognized. In fact, while a sometimes bitter power struggle is peaking, the fortunes of the company may be sliding downhill. In other cases, power struggles are part of a healthy transition. According to these authors, family and company transition will be more productive when they are simultaneous. The external problem involves the older generation making use of flexibility and new ideas of the succeeding generation. Third party involvement may help to prevent irreparable family rifts and company stagnation. Dialogues between all the parties-family managers, employees, and outsiders - can also help.

Figener 1994) states that the stream of management research address leadership, succession, and executive development issues, significant gaps in the literature remain. In particular few studies have systematically explored the systems by which the future leaders (successors) of the family firms re developed. This research present a descriptive study in which the successor development approaches of the small medium-sized family and no family firms are compared. The findings indicate that (1) family firms favor more personal, relationshipcentered approaches to successor development; (2) no family firms prefer formalized, task-oriented development approaches; and (3) company size has no real effect on successor development.

Galiano and vinturella (1995) have examined the prevalence of biases towards females and some underlying perception in regard to gender within the context of the family business. The implications of gender bias for the well-being of family business are analyzed, with particular reference to the issue of succession planning. Women's changing professional and family roles are also examined.

Harvey and Evans (1995) state that the succession processes in family business are well chronicled in the business literature. Most of the research focuses on the process of transferring power within the business-family. What has not been as closely examined is the after-succession environment that exists when the management and leadership of the family business are passed on to the next generation. This article addresses that organizational climate and the potential problems in the business-family if post-succession issues are not identified and addressed and suggests some steps that will be helpful in producing complete succession success.

Balakrishna (1996) states that the subjective performance measures have been widely used in research on market orientation and its presumed link to company performance. However, only a small number of studies have examined the link between subjective performance measures an objective ones. This study replicates 
earlier search and extends previous findings using a broader sample of firms than in most previous studies, and uses slightly different measurement scales. It founds that their correlation between objective and subjective performance measures. However, this correlation is far from perfect and the article concludes that research should attempt to validate their results by using both types of measures.

Poza et.al (1997) has examined the research on family business. Family businesses participating in the partnership with family business at the weather head school of management, case Western Reserve University, completed questionnaires that explored family and business culture of practices. The completed questionnaires show that CEOs generally perceived the practices, cultures, and succession processes more favorable than both other family members and non-family managers. The questionnaires indicate important relation between family and family firms cultures, suggestions the importance of intervention approaches that the whole system of family and business. Non-family manager's perceptions of family firms differ, posing challenges to the full utilization of their capabilities. Age is significant in explaining some of the differences in perceptions within and between family and non-family respondent. Finally, responses indicate that planning practices, communication processes, and the use of boards are influenced by family ownership and are positively related to some features of firms and family.

Amber and kokkinaik (1997) has examined 46 empirical studies which has assessed performance measurement in marketing. The paper reports on two highly relevant topics in regard to performance measurement: (1) subjective and objective measurement; and (2) financial and non-financial performance measures. Furthermore, the paper provides a tabulated summary of a comprehensive literature review of the types of performance measures utilized in recent literature. Firstly it was found that their seems to be agreement about the use of a subjective measurement perspective as an acceptable means of measuring performance, and that this is the preferred means of measuring performance of researchers. Secondly, the literature review identified that businesses are not defining performance only in terms of the traditional financial measures- they are adopting the new frameworks and methodologies. However, this change is not as prominent as might be thought, as financial measures still predominate in research results. Furthermore this review of performance measures also identified that current measurement selection by researchers is somewhat arbitrary rather than scientific, which is not assisting in the development of a "general performance measures".

Stavros (1998) states that the involvement of and the reason for the involvement of offspring in their parents firms can significantly affect the firms further. In this paper, a conceptual model is presented that explains the decision process through which the most suitable level of involvement for the next generation in the firm may be assessed. The decision process involves four factors: family, business, personal, and market. These factors set the context for managing intergenerational transition in family firms.

Nam and Herbert (1999) states that the immigration businesses in the United States are a vibrant and growing part of the economy, and their similarities and differences to other family businesses in U.S. and worthy of investigation. This paper examines two elements of Korean immigration businesses in metro-Atlanta: characteristics (ethnic business, general family business, owner and successions planning, strategic planning, and conflict and communication) and key success factors. There were 93 respondents in this exploratory study. This paper discusses the result and implication of the study.

Dunn (1999) states the finding from three longitudinal case studies forming part of ongoing doctorial research into the activities and dynamics of business-owning families as they address the task and issued required during their succession processes. Specifically, the paper qualitative explores the nature, characteristics and effects of family relationship dynamics in three family business system undertaking the transfer of controlling ownership of the next generation ( from father to son). A model is presented to describe the sources of anxiety "imperatives" and their management during transition processes. Conclusions are drawn about the characteristics of emotional dynamics in business-owning families and how these can, over time, hinder of help families manage these tasks.

Adler and kwon (1999) define the concept of family capital and propose that family capital has potential impact on business performance. This study investigates whether the use of collaboration as a problem solving technique with in family business as a moderating effect on the relationship between family capital and family business performance. Additionally, this study investigates whether the existence of the conflict i.e. both tasks and relation within family business as a moderating affect on the relationship between family capital and family business performance. Specifically, it is theorized that (1) family capital will positively affect family business performance, (2) conflict and collaboration will moderate this relationship. The hypotheses are tested using data 
from the survey of family business collected by the centre for entrepreneurship family business as Texas Tech University.

Agarwal and jaffe (2000) states the empirical research findings on the success of post acquisition performance have generated inconsistent results. This has been attributed to the choice of performance measurement indicators. This paper analysis and evaluates existing performance indicators that have been implied in the literature. It is argued that to overcome the limitations found in financial indicators of performance a need to pursue multiple measures of performance in post acquisition research is needed. It also argues that the motives for the transaction should also be included as performance indicators. These hybrid approaches will researches and practitioners to measure the overall success of acquisition.

Santiago (2000) states hat the western research suggests that family business owners must prepare for leadership succession in a systematic manner to ensure continuity. A review of succession experiences of eight family businesses in the Southeast Asian country to the Philippines seems to indicate that the key to smooth succession for group oriented families is not entirely dependent on succession planning. Rather, a family business's smooth successions dependent on the process being consistent with family values. In fact, valuing the preservation of the family unit helps to avoid the ill effects that normally accompany the absence of succession planning.

Littunen and hyrsky (2000) have examined factors that influence that survival and success of 200 Finnish family and non family in the metal based manufacturing industry, over the first three years of their operations. The features that this study includes owner-manager personality attributes, entrepreneurial competence, and motives for the start up. Strategic choices of the firms were also examined. The study found that family firms were better equipped to survive beyond the early entrepreneurial stage than were no family businesses. The entrepreneurial abilities and resources of the family business owner enable them to operate relatively succession in the nearby market, often with one unique product. The family firms were more conscious of survival and family well being than profitability on market position. A higher mortality rate was discovered among the non family firms. Failed firms were often established with unrealistic expectations, and their performance deteriorated rapidly after their early success.

Manikutty (2000) use the resource based view of firms to understand the strategic responses of nine family groups to the more liberalized environment in India's emerging economy. Using the concepts and empirical finding in the resource-based view (RBV) stream of literature, this manuscript offers six hypotheses related to the restructure of business portfolios, structural changes within organization, and the induction of professional family and non family members. The article also identifies five emerging trends in the responses and uses them to test the hypotheses. Data from published sources indicate a high degree of support for the hypotheses. The study show that resources based view of the firm provides an excellent theoretical framework for understanding and interpreting these responses and suggests directions for further research.

Veliyath and Ramaswamy (2000) have examined that CEO compensation reflects two common bases: (a) the dominant use of the agency theory perspective and (b) the almost exclusive use of U.K and U.S. samples. Agency theory views compensation as a consequence of the incentive contracts and the processes to corporate governance. However, little is known about the determinants of CEO compensation in developing countries. Considering that foreign direct investment of U.S. multinational enterprises increased 10-fold over the past decade, mostly in developing economies, there is great need to understand the dynamics of pay setting in these foreign contexts. Overall, there is an imperative need o explore alternative theoretical perspectives as well as investigate nontraditional context to broaden existing theoretical premises. In an attempt to address this need, this study investigates the CEO'S social embeddedness and overt and covert power as determinants of the CEO pay in a sample of Indian family-controlled firms. Using a time series, cross sectional regression analysis, we find family shareholdings and the percentage of inside directors on the board (identified as bases of overt power for the CEO) to be predominant influences on CEO pay. By contrast some of the identified bases of covert power, such as CEO tenure, age, education, and firm diversification are not significant surprisingly; controls for firm size and performance also exhibit no influence of CEO pay. These findings offer a useful point of reference against which results from western studies can be compared to formulate more holistic theories CEO pay.

Steier (2001) states that the relationships and connectivity play an enhanced role in most models of the new economy. For many firms, strategic advantage resides in the social capital (or relational wealth) they are able to nourish and maintain. This important asset is accumulated overtime and easily traded and transferred. For family firms with long term continuity goals, the transfer and management of his largely intangible asset are a most 
significant activity. This research is based on interviews of next-generation entrepreneurs in 18 different firms. It contributes to the family business and more general management literature by identifying different way in which relational wealth is transferred, created, and managed. Four different mode of transferring social capital emerged from the data: unplanned, sudden successions; rushed successions; natural immersion; and planned successions and deliberate transfer of social capital. Additionally, seven means of managing social capital emerged: deciphering existing network relationships, determining criticalities, attaining legitimacy, clarifying optimal role, managing ties through delegation and division of labor, and striving for optimal network configuration and reconstructing network structure and content. This paper concludes with a series of propositions for further research.

Tan and fock (2001) states that the families control more than half of the corporation in East Asia. The contribution of the family business to Asia's economic growth is predicated upon successfully growth their businesses. Many family businesses in East Asia, spanning countries such as Taiwan, Hong Kong, Indonesia, Singapore, and Malaysia, are Chinese owned and managed. Some claim that these business will never develop into full-fledged multinational enterprise because have successfully made the transition. This paper presents an in-depth study of five Chinese family businesses in Singapore that have successfully made the transition in growth and size and across national boundaries and family generation. There business empires extend into in the Asia pacific region. This paper highlights the key success factors of these five noteworthy family businesses that enabled them to make these growth transitions.

Rouvienz (2001) states that the sale of family business often gives rise to emotions that can still haunt family's year after the sale. However, some families -combine generations of experiences and succeed in turning it into a positive experience by re-creating a new family business venture. The objectives of this research re to demonstrate that serial business families that constitute global phenomena and to identify patterns in how and why they re-create business. The compilation and analysis of in-depth interviews with nine serial business family from around the world show that they follow a three-stage process and that the original business, in terms of family, ownership business and governance has a strong influence on what is re-created and how it is recreated. The fresh motivation and the strong commitment of serial business of serial business families, combined with renewed entrepreneurial sprit, could serve as an inspiration for all families in business to reconsider their strategic agendas in the content of new economy.

Rutten (2001) has examined major debates on entrepreneurship in south and Southeast Asia indicates an emphasis on collective forms of business organization. While earlier views argued that collectivism in business activity was one of the main causes of Asia's backwardness, mare recant nations emphasis that family enterprises and business net works account far Asia's economic rise. This article compares the form of business organization of rural entrepreneurs in India, Malaysia and Indonesia. It is based on empirical research among Hindu small -scale industrialist in central Gujarat, Chinese and Malay owners of combine harvesters in the Muda region, and Muslim owners of iron foundries in Central Java. The findings are in line with studies on European entrepreneurs. There is therefore reason to reconsider the notion of significant differences in business organization between Asian and European entrepreneurs.

Astrachan et.al (2002) have examined the alternative method for assessing the extent of family influence on any enterprise, enabling the measurement of the impact of family on outcomes such as success, failure, strategy, and operations. This proposed method, utilizing a standardized and valid instrument -the F-PEC- enables the assessment of family influence on continues scale rather than restrict its use as a categorical (e.g., yes/no)variable. The F-PEC comprises three scales: power, experiences, and culture. This article discusses these scales in detail.

Bird et.al (2002) state that the establishment of field of study or a discipline with academic or professional standing requires, among other things, a body of knowledge that expands understandings of that domain. This paper looks at the literature an establishing a unique field of study, reviews the foundational research in family business (1980s) and four recant years (1997-2001) of published family business research found in several outlets. We find that family research is becoming increasingly sophisticated and rigorous. This bodes well for the development of in independent field for family business. Recommendations or offered to further the professionalization of family business as an academic and professional domain.

Curimbaba (2002) has examined the professional experiences of female heirs in a verity of family business located in three states of the Brazilian southeast. The aim is to analyze both how the family and business structures affect the daughters' visibility in managerial positions and the resulting gender relations. Twelve 
open-ended, in-depth interviews were conducted. The responses were analyzed, and pathways were classified according to Gersick, Davis, and Lansberg (1997) three-dimensional development model of family business. Three groups formed to describe the daughters' experiences: invisible, professional, and anchor.

Cragg and hussin (2002) have conducted an industry-level study that seeks to identity empirical regularities between firm strategy, management style, organizational structure and performance in Spanish fresh fruit and vegetable (fresh produce) industry using strategic group analysis. Groups were formed from key dimensions reflecting' firms strategic orientations. Performance levels did not differ systemically between strategic groups, but performance was found to be influenced by the alignment between entrepreneurial culture and organizational structure. A move towards greater flexibility and/or adopting an entrepreneurial style is both likely to contribute to an improvement in the overall performance of the firm.

Mazzola and Marchisio (2002) have suggested that going public affects the capacity of companies to pursue growth and profitability in the long run. Their study combines the result of transversal and longitudinal analyses of two databases of fast-growing Italian companies and IPOs and compares the result with nonfamily owned business that went public during the same period. Studies of companies' growth show two main reasons for growth: external causes due to evolution in progress in the competitive environment and internal causes brought about by management ambitions. In either case, growth provides companies with three main advantages: the ability to increase value, higher market shares, and increased productivity. Italian empirical research shows the great difficulties that both small and large companies have growing. It is estimated that most companies, especially small ones, are family owned. The literature shows that family-owned companies face particular obstacle and that the IPO appears to provide them with some advantages.

Cadieux et.al (2002) state that the succession is one of the most studied aspects of family business. However, although it is estimated that women own more than $33 \%$ of such organizations, to our knowledge, few studies focus on succession in them. The objective is to explore and understand the process of succession in familyowned business run by women. This paper presents the result of a case study of four women who own and run family business in the manufacturing sector and who have shared the management of their organizations with their successors for at least three years.

Chua et.al (2003) has conducted a survey of the issue facing top executives in 272 Canadian family firms. Results show that succession is their No. 1 concern, thus supporting the predominant focus of family business researchers on successions issue. Results also show that concern about relationships with nonfamily managers is a close second in importance. They have used agency theory to explain why relationships with non family managers are so important. Empirical results show that both the extent and the criticality of firms' dependence on nonfamily managers are statistically significant determines of the importance. This study implies that relationships with nonfamily managers is neglect research topic and points to a new direction for research in family business management.

Sharma et.al (2003) have examined the theory of planned behavior to hypothesize the influence of the incumbent's desire to keep the business in the family, the family's commitment to the business, and the propensity of trusted successor to take over on the extent to which family firms engage in succession planning activities. To test these hypotheses using data collected from presidents in 118 family firms. The results show that the propensity of a trusted successor to take over significantly affects the incidence of all successionplanning related activities. Succession planning may, then, be the result of push by the successor more than of pull by the incumbent. Such a view has negative implications for the successions process that the family firms in our sample follow.

Auch and Lee (2003) have examined the proponents and critics of Asian economic organization that have been preoccupied with the ideal-typical management model of family business and have rarely identified the change and continuity in these management structures through an analysis of family-controlled business groups in Singapore and South Korea before and after the Asian currency crisis. In their view, these business groups professionalized their management, but retained family control and corporate rule before crisis. The crisis, however, increased the pressure on such groups to relinquish family control and corporate rule. Singaporean Chinese business groups tended to loosen their tight grip on corporate rule by absorbing more professional managers into their upper echelons. The surviving Korean chaebol, however, intensified family control. Only a few chaebol, which were on the brink of bankruptcy, relinquished corporate rule to professional managers. We argue that the market, cultural and institutional factors as suggested in the existing literature, state capacities and strategies do matter in shaping the changing management structures of business groups. Drawing on their 
analysis, researchers will be able to conduct comparative studies of family businesses across East Asian societies, of organizational imitation, and of the role of the state in influencing management models.

Zahra and Sharma (2004) state that family business continues to grow. Six key trends have become evident. These trends include a continuing pursuit of a research topics such as succession, a strong for preference for practice orient research methods, a tendency to borrow heavily from other disciplines without giving back to these fields, and a strong preference to talk to other researchers conducting researches on family firms-failing to communicate with scholars from other disciplines. They have suggested strategies to expedite the growth of family business research towards better understanding the paradoxes faced by family business manager, deepen insights into the problem they encounter, improve rigor in reported research, find ways to promote a dialog with scholars in sister disciplines, and give back to the disciplines from which we borrow heavily.

Sharma (2004) has examined the review of 217 referred articles on the family business studies; the literature is organized according to its focus on individual, interpersonal or group, organizational and social levels of analyses. An assessment $f$ the status of our current understanding at each level is provided and directions for future research are suggested. A discussion of definitional issue, bases of distinctiveness, and family firm performance is used to help understand the domain or scope of the field. Methodological issue and strategies aimed to enhance the pace at which the field achieves a distinctive legitimate place in organizational studies re presented.

Craig and moores (2005) suggest that the research is the measurement and management tool known as the balanced scorecard (BSC) can be applied in the family business context. In this article they add families to the four BSC perspectives (financial, innovation and learning, customer internal process) and illustrate how this can assist business development, management and succession planning in family owned businesses. They use an action research project to highlight that how family business can professionalize their management by the adoption of a BEC strategy map that includes a family business focus and links the core essence of the family business with the values and the vision of the founder of the strategic initiatives of the family business. The FPEC scale constructs of power, experience and culture are used to introduce a PEC statement that identifies and articulates the core essence of the family business.

Dyer (2006) has examined the performance of family- owned firms. He suggests that the most of the research fails to clearly describe the "family effect" on organizational performance. The "family effect" based on agency theory and the resource-based view of the firm, is described and propositions and generated that examine the relationship between families and organizational performance. Implication for theory and research are also discussed.

Westhead and Howorth (2006) state that the agency and stewardship theories are used to explore associations between ownership and management profiles and the performance and objectives of family firms. Using data from privately held family firms in the United Kingdom, a range of performance measures and objectives were examined. Multivariate regression analysis detect that closely held family firms did not report superior firms performance. The result show that the management rather than the ownership structure of a family firm was generally associated with selected firm-performance indicators and no financial Company objectives. Although family CEOs were associated with lower propensity to export, presented evidence generally fails to suggest that private family firms should avoid employing family members in management roles.

Lee (2006) has examined the influence of family relationships on attitudes of the second generation working in their parents' family business. Two specific family variables organizational commitment, job satisfaction, and propensity to leave. Relationships among outcome variables are also examined. A survey questionnaire is used as the research instrument.

Blumentritt (2006) had examined the relationships between the existence of boards of directors and advisory boards and the use of planning in family business. It is argued that both of the primary roles of boards, the governance of a firm's management team for the firms stake-holder and the provision of valuable business resource of the firms management team, are significantly related of the use of planning activities in family business. The empirical evidence, dawn for the survey of more than 130 family businesses, largely supports the hypotheses. Conclusions and suggestions for future research close the article.

Auken and verbal (2006) state that the survival of a family business as partially dependant on spousal commitment. The discussion of launch a business should depend not only on analysis of the opportunity, but 
also on the degree to which one's spouse shares a common vision about the goals, risks, and rewards of the business. Models and testable hypotheses are devolved to guide empirical research on the antecedents and consequences of spousal commitment to family business. The model can benefit individual considering the launch of a business, couples that currently own a business, business consultants, and university instructors teaching entrepreneurship courses.

Venter et.al (2006) state that the successor-related factors that can influence the succession process in small and medium-sized family business are empirically investigated. This study was undertaken in South Africa among 2,458 owner-managers and successors in 1,038 family businesses. These respondents were identified via a snowball-sampling technique. A total of 332 usable questionnaires were returned. The dependent variable in this study, namely. The perceived success of the succession process, is measured by two underlying dimensions: satisfaction with the process and continued profitability of the business the empirical results indicate that the successor-related factors that influence satisfaction with the process are, on the one hand, the willingness of the successor to take over and the relationship between the owner-manager and successor, on the other hand. The continued profitability of the business is influenced by the willingness of the successor to take over the business, the preparation level of the successor, and the relationship between successor and owner-manager. The relationship between owner-manager and successor is in turn influenced by the extent to which interpersonal relationships in the family can be described as harmonious. Based on these findings recommendation for successful succession are offered.

Motwani et.al (2006) have examined the results for a survey of 368 family-owned small to medium size enterprises (SMEs) with regard to importance, nature, and extent of succession planning. By categorizing SMEs according to their annual revenues, total number of employees, and number of family members employed within the firm, significant differences were found between larger and smaller firms. Consistent with extent literature, the findings reveal that most family members join the firm for altruistic reasons. Issues related to family relationships were related as significantly more important in firms in which in more family members were employed within the firm. Moreover, for firms with less than US $\$ 1 \mathrm{~m}$ in revenues, a high priority is placed on selecting a successor who posses strong sales and marketing skills. The findings show that regardless of their size, it is important for family-owned business to developed a formal plan for succession, communicate the identity of the successor, and provide training/mentoring to the incumbent CEO.

Denoble(2007) states that the importance of succession planning in family owned business in focused on identifying the key dimensions that could comprise a family business the self efficacy scale. He employed an exploratory qualitative research methodology by querying a group of family business presidents to describe the skills critical for success. Used a resource-based perspective and relevant family business succession literature, they organized this feed back into a framework depicting the key challenges associated with leadership succession. The precedents comments highlight a set of general and family business skills requirements that fall into the domains of social and human capital.

Cadieux(2007) has examined the succession process- the joint management and the withdrawal phase- differ from preceding phase in that they mark the successor's official entry into the family business as future head and the gradual retirement of the predecessors. Alone at the helm until that point, processors are faced with an important period of transition in their life where there role as leader is replaced by other rules that have not yet been clearly defined in the existing literature. Using a case study research strategy this article presents a typology of predecessors roles during and after instatement of the successor from five small and medium sized family business that have successfully completed their first generation transfer.

Chitoor and das(2007) state that the impact on succession performance on succession to a non family professional manager as compared to family member, commonly referred to as professionalization of management. An important distinction is drawn between family owned and family managed business and family owned and professionally managed businesses. Then, drawing from case studies on succession process in three Indian family business groups. The article puts fourth five propositions pertaining to the impact of professionalization of management on succession performance. Several directions for further research are indicated.

Sciascia and mazzola (2008) states that the performance of family firms is growing, but results are mixed, especially for non listened companies. Thus on the bases of co presence of benefits and disadvantages of family involvement in ownership and management, they explored the presence of non linear effects of these two variables on performance. We run regression analysis on data drawn from 6666 privately held family firms in 
Italy: a negative quadratic relationship between family involvement ion management and performance was found, but we find association between family involvements in ownership and performance. Their results suggest that in privately held firms the positive effects that previous literature associates with the presence of family managers do not appear strong enough to compensate for the disadvantages deriving from a non monetary orientation, nor do they compensate for the costs deriving for the need to solve conflicts between family managers and the impossibility of enlarging the companies social and intellectual capital through the employment of non family managers. Moreover, the quadratic nature of the relationship cause for greater attention to be paid to these effects by family business owners, especially in those cases where family involvement in management.

Massis et.al(2008) states that research on management's succession is a dominant in the family business literature. Little systematic attention has been given to the factors that prevent intra-family Succession from occurring. Based on a review and analyses of the literature, this article presents a preliminary model on the factors that prevent intra-family succession.

Allouche et.al(2008) state that the family business have under gone rapid development in the past two decades. Broadly speaking, such companies perform better than non family businesses, as recent investigations in Japan support. To obtain a more precise result, this result has applied to the Japanese context a research methodology that has proven its worth in western cases. On the bases of data covering the years 1998 and 2003, we find better performance among family business in Japan.

Tatoglu et.al (2008) has examined the key issue for much family- owned business (FOBs) is intergenerational management succession. This article investigates the dynamics of the succession process for FBOs that have already taken the succession decision and have selected their successors. The primary goal of the study is to delineate the factors behind the section process by investigating selection, training and entry mode of successors as well as the involvement of family members and stakeholders in the succession process. Data from the predecessors of 408 FOBs in turkey reveals a number of insightful findings regarding major characteristics of the FOB succession process including the views of processors on the succession process, successor selection criteria and the post-succession period. This is first systematic study with the succession process in Turkish FOBs, which previously has been informed only by anecdotal evidence.

Hall and nordquist (2008) state that the purpose is to challenge the dominant meaning of professional management in family business research and to suggest an extend understand of the concept. Based on a review of selected literature on professional management and with insights from culture theory and symbolic interactions, they draw on interpretive case research to argue that professional family business management rests on two competencies, formal and cultural, of which only the former is explicitly recognized in current family business literature. They have elaborated on the meanings and implications of cultural competence and argue that without it a CEO of a family business is likely to work less effectively, no matter how good the formal qualifications and irrespective of family membership.

Mazzola et.al (2008) has examined the issue of training next-generation family members once they have joined the management team in their family firm. The qualitative analysis of strategic planning process of 18 Italian family firms show that involving next generation family members in the planning process benefits their development process. The findings indicate that this involvement provides the next generation with crucial tacit business knowledge and skills, facilitating interpersonal work relationship between incumbents and next generation leaders and building credibility and legitimacy for the next generation. The comparative analyses of the cases allowed us to identify the five variables that seem to combine in explaining much of the observed differences in the amount and compositions of benefits experienced in the 18 firms. Their findings extend current understanding topics in family business: the post entry phase tanning of the next generation and strategic management in family firms.

Royer et.al (2008) state that the succession is a challenge to family business for a number of reasons, including the need to address the issue of intergenerational handover. This article focuses on one aspect of succession in family business by investigating when family members are preferred as successor. Results from 860 family businesses indicate that specific (tacit) knowledge characteristics combined with a favorable transaction atmosphere, in certain context, make a family member the most suitable successor. A conceptual model is presented that outlines when inside family succession preferred. 
Sundaramurthy (2008) has presented a model of sustaining trust based on an integration of trust literature with the family business literature. The basic premise of the model is that trust in dynamic and multiple dimensions of trust need to be developed through structures and processes to sustain interpersonal trust inherent in the early stages. Implications of the model and future research directions are outlined.

Dyer and dyer (2009) state that the recent research on family business has focused on how the family affects business performance. Their commentary suggests that researches should also consider how certain variables affect both the business and the family. Suggestions for how to do such research are presented.

Basco and Rodriguez (2009) state that the research contributes to the family business literature by empirically demonstrating that family enterprises that give more emphases to family and business as a whole have better family results and similar business results when compared to these enterprises that limit governance to only the businesses. The article includes a review of the literature, and it identifies a set of four basic dimensions that focus on different aspect of family enterprise. The study then combines measures of these dimensions to describe both the governance and the nature of the family and the business. A representative sample of 732 Spanish family enterprises enabled the research to reveal empirical support for the theory positing that balanced attention to governing the subsystems is an effective route to family enterprise management.

Sorenson et.al (2009) have examined the new concept, the family point of view, and provides theoretical arguments resulting in the following hypotheses (a) the family point of views emerges from collaborative dialogue, which helps development agreement to ethical norms;(b) the presence of ethical norms further helps cultivate social family capital; and (c) as a source in a family business, family social capital is positively related to the family firm performance. Using structural equation modeling, an exploratory test of 405 small family firms found support for all three hypotheses. The findings indicate a fully mediate relationship among collaborative dialogue, ethical norms, family social capital, and firm performance. The study not only highlights the importance of moral infrastructure in family firm but also helps clarify components of family capital.

Debicki et.al (2009) state that the analysis of 291 family business articles published in 30 management journals between 2001 an 2007 reports the contributions of individual scholars and academic institution to family business research. To better understand the interrelationship among scholars who have contributed to family business research, a network analysis of coauthor relationship was conducted. The authors were providing a content analysis of the articles and offer suggestion for future research. By analyzing the who, where, and what of family business research, the reasons why the developmental trends have occurred and how the fields momentum, can be maintained and directed towards productive ends become clearer.

Cater and justrin (2009) have conducted an exploratory to better understand the development of successors in the small family business, including their approach to the leadership of the firm. It examined variables (and their relationships) that help to explain family business successor leadership. A case study was followed, used grounded theory analysis of qualitative interviews of the top managers of six family businesses. It provided six propositions for future research-namely, concerning positive parent-child relationships, acquiring knowledge, long-term orientation, cooperation, successor roles, and risk orientation.

Distelberg and Sorenson (2009) has extended and explained current system views of family business and provides a frame work for interpreting family business holistically. The framework extends the definition of family-fist that represented balanced system emphases. in addition this article discusses the goals, resource transfer, strengths, and limitations of each type of system and describes how firm adaptability and resource flows influence and change these family business systems; it argues that to understand family businesses health, one must understand the values and goals that guide the family business, business, and ownership systems, as well as the overfill family business system; and it presence an inclusive definition of family and business based on systems membership.

Kowalewski et.al (2010) has investigated the influence of family involvement on firm performance in an emerging market economy. Using a panel of 217 polish companies from 1997 to 2005, the authors find an inverted U- shaped relationship between the share of family ownership and firm performance. The data also reveal that firms with family CEOs are likely to outperform their counterparts that have non family CEOs. The results take into account the endogenous of family ownership and are robust to a number of specification checks. 
Chrisman et.l (2010) has examined the 25 articles that have been particularly influential in shaping the state of the art of research on family businesses. These works identified based on a citation analysis of family business article published ever the past 6 years in the four journals that publish most of the research. The authors summarize those influential studies and discuss their most important contributes to scholars' current understanding of family business. By identifying common Themes among those studies, the authors are able to provide directions for future research in the field.

Hot et.al (2010) state that the field of family business research is advanced by further examining the validity and reliability of Klein, astrakhan, and simonies' family influence of power, experience, and cultural scale. Data from 831 family businesses ale analyzed to assess the measures construct validity using exploratory and confirmatory techniques. The hypothesized three factors model emerged to include culture, power, and experience. Extending the previous effort, the measures convergent validity was tested by assessing differences between the measures score and the desires of the senior generation and the commitment of the next generation. Results support an initial level of convergent validity.

Casillas et.al (2010) has examined the present research to improve scholars understanding of the relationship between entrepreneurial orientations (EO) and the growth of family firms in two areas. The authors propose that the EO-growth relationship is contingent on different contextual variables- environmental dynamism and environmental hostility-and an internal variable-generational involvement. Also, they consider EO to be a composite construct integrated from and related to different independent dimensions. Using information from 317 Spanish family firms, results show that (a) EO positively influences growth only in second- generation family businesses; (b) the moderating influence of the generational involvement is related to the risk- taking.

Lorna Collins, Nicholas O'Regan, (2011 Family business has evolved significantly over the past decade and today it is a well accepted and respected field of enquiry. In gaining academic acceptance, it has retained its practitioner roots. The paper argues that it is time for a re-think because the focus of previous family business research has become somewhat convoluted with small- and medium-scale enterprises research (at least in the UK) and with particular parts of the family business rather than the entire family business system. To continue its impressive upward trajectory, family business management and research needs to embrace new theoretical perspectives and approaches, particularly those that come from disciplines such as psychology that at the moment have tenuous links to family business studies. It also needs to embrace learning that can be gained from practitioners and develop useful discourse between stakeholder groups in the family business community

Alexandra Dawson (2012) The main focuses on the construct of human capital in family businesses. It makes three key contributions. First, it furthers our understanding of human capital in family businesses by identifying the underlying dimensions of human capital, involving not only knowledge, skills and abilities but also individual attitudes and motivation. Second, the article puts forward the conditions under which family businesses can achieve and sustain over time an alignment of interests between individual human capital and organizational goals. These conditions will vary depending on whether the external environment is static or dynamic. Third, the article heeds the call, shared by strategic management scholars, to focus on the individual level as well as on the (predominant) group- and organizational-level constructs

\section{Conclusion And Implications}

This article has tried to give an overview about what family firms actually are, and how far extant academic literature is in researching these particularities. Accordingly, this article has delivered an extensive overview of existing literature on family firm research, and confirmed that this research area is still in its infancy. The role of business in the society has witnessed a dramatic change in the recent times. Yesterday, it was the business as family. Today, it is the family as business. And tomorrow, it will be the business of the family to ensure that there is a future for both the business and the family. While radical strategy, operations, and financial transformation is given for any corporation that hopes to survive the trauma of competing in the post-liberalization market-place, India's business houses have yet another agenda for change: rewriting the role of the family. It is the family that must initiate and implement the changes that are involved. It is now essential for the family to prevent the conflicts between the rules, messages, and expectations for behaviour in each system that are weakening business. A series of vital roles have to be played by the business family to make family business survive. The involvement of the family in managing the business house must necessarily migrate from management to influence, from exercising the powers of the executive to invoking the rights of the shareholder. Owners have to distinguish between managing wealth and managing businesses. The family may not be good at both. 
The critical function for the family in guiding its businesses will prove to be able governance. The business house finds itself competing for capital, people, and customers without special protection, the quality of its corporate governance will be a vital differentiator. Professionals should look after the operational side of the business while family members should look after the entrepreneurial side. Future work might develop empirical approaches to investigate such sources of differences between family firms and nonfamily firms. Moreover, it will be important to understand the interaction between family values and the formal institutions within a country. If family values are indeed (partially) exogenous and do not simply adjust in response to the economic environment, a more complicated dynamic between family values and formal institutions will arise. . Our understanding of the nexus between family and firm should improve with more microeconomic studies that analyze how the structure of a given family - including its size, gender and age composition-alters the strategic choices and eventual performance of the family firm. Because of the very detailed data required to perform such analysis, future micro research on this work might be forced to proceed on a country by country basis. Ultimately, we believe that a richer understanding will be gained from the accumulation of many such detailed studies, spanning a wide range of countries with different cultural norms and formal institutions.

\section{References:}

[1] Agrawal A and Jaffe J F (2000), "The Post-Merger Performances Puzzle”, Advances in Mergers and Acquisitions, VOl.1.pp.7-41.

[2] Alexandra Dawson" Human capital in family businesses: Focusing on the individual level" Journal of Family Business Strategy 3 (2012) 3-11

[3] Allouche Jose, Amman Jaussand and Kurashina (2008) "The Impact of Family Control on the Performances and Financial Characteristics of Family Versus Non-Family Business in Japan, A Matched-Pair Investigation", Family business review, VOl.21, No.4, pp.315-330.

[4] Ambler T and Kokkinaki F (1997), "Measure of Marketing Success", Journal of Marketing Management, Vol.13.pp.665-679.

[5] Amit R and Schoemaker P (1993), "Strategic Assets and Organizational Rent", Strategic management journal, Vol.14 (1), pp.3346.

[6] Anderson R and Reeb D (2003), "Founding Family Ownership and Firm Performance”, Journal of Finance, Vol. 58(3), pp.13011327.

[7] Astrakhan J H (1988), "Family Firm and Community Culture", Family business review, Vol.1, pp.165-189.

[8] Astrakhan J H, Klien S B and Smyrnious K X (2002), "The F-PEC Scale of Family Influence, A Proposal for Solving the Family Business Definition Problem", ", Family business review, Vol.15,pp.45-55.

[9] Astrakhan Joseph H, Sabine B Klien and Komas X Smyrnious (2005)," The F-PEC Scale of Family Influence Construction, Validation, and Further Implication for Theory", Family business review, Vol.3, pp.234-256.

[10] Auch Lai Sui Tsui and lee (2003), "The State Matters, Management Model of Singaporean Chinese and Korean Business Groups", Organization Studies, Vol.24, No.24, pp.507-534.

[11] Auken Howard Van and Werbel (2006), "family dynamic and family business financial performance, Spousal commitment," Family business review, Vol.19, No. 1, pp.49-63.

[12] Balkrishnan S (1996), "Benefits of Costumer and Competitive Orientations in Industrial Markets", Industrial Marketing Management, Vol.25, pp.257-269.

[13] Barnes Louis B (1994), "Transferring Power in the Family Business", Family business review, Vol.7, No.4, pp.377-39.

[14] Barney J (1991), "Firm Resource and Sustained Competitive Advantage", journal of Management, Vol.17, pp.99-120.

[15] Basco Rodrigo and Rodriguez (2009), "Studying the Family Enterprise Holistically Evidence for Integrated Family and Business System", Family Review, Vol.22, no.1, pp.82-95.

[16] Benedict (1986), “ Working on Sociological and Economic Prespective”, Family business review, vol.21,pp.31-56.

[17] Berenbeim Ronald E (1990), "How Business Families Manage the Transition from Owner To Professional Management", Family Buiness Review,Vol.3,no.1,pp.69-110.

[18] Bird Barbara, Welsch, Astrachan and Pisturi (2000),"Family Business Research, The Evolution of an Acedemic Field", Family Business REVIEW, Vol .15,NO.4,PP.337-350.

[19] Blumentritt Timothy (2006), "Relationship Between Boards and Planning in Family Business", Family Business Review, Vol. 19, no.1, pp.65-72.

[20] Buuren (2009), "Multinational Acquisition Integration, The Role Oo National Culture IN Creating Synergies", International BusinessReview, Vol. 14 PP.269-288.

[21] Cadieux Losise, Lorrian and Hugron (2002), "Sucession in Women-Owned Family Business. A Case Study", Family Business Review, Vol. 15,NO.1,PP.17-30.

[22] Cadieux Louise (2007)," Succession in Small and Medium-Sized Family Business", Family Business Review, Vol.20,PP.95-109.

[23] Casillas Jose C (2010), "A Configrational Approach of the Relationship Between Enterpreneurial Orientation and Growth Of Family Firms, "Family Business Review, Vol.23,no.1,pp.27-44.

[24] Cater John James And Justrin (2009), "The Development Of Successors From Followers to Leaders in Small Family Firms", Family Business Review, Vol.22,no2,pp.109-124.

[25] Chakravarth B S (1986), “Measuring Strategic Performance”, Strategic Management Journal, Vol.7(5), pp.437-458.

[26] Chittoor raveendra and Das (2007), "Professionalization of Management and Sucession Performance -A Vital Linkage", Family Business Review, Vol.20.NO.1,pp.65-79.

[27] Chrisman James J, kellermann, Chan and Liano (2010), “ Intellectual foundations of Current Reseach in Family Business, An Identified and Review of 25 Infulantial Articles", Family Business Review, Vol.23,no.1,pp.9-26.

[28] Chua Jess H, Chrisman James J and Sharm pramodita (2003), “ Succession and NonSuccession Concerns Of Family Firms and Agency Relationship With Non Family Managers”, Family Business Review, Vol.16,pp. 89-108.

[29] Cooper A (1986), “Enterpreneurship and High Technology”, In D. Sexton and Smilor (Eds). The art and science of entrepreneurship, pp.153-168. Cambridge, Ballanger publishing company.

[30] Cragg P M King and H Hussin (2000), "IT Alignment and Firm Performance in Small Manufacture Firms", The Journal of Strategic Information Systems, Vol.11,pp.109-132. 
[31] Craig Justin and Moores (2005), "Balanced Scorecards to Drive the Strategic Planning Of Family Firms", Family Business Review, Vol.18, NO.2, 22, PP.105-122.

[32] Curimbaba Florescence (2002), “The Dynamics Of Women’s Roles as Family Business Managers”, Family Business Review, Vol.15,no.3,pp.239-252.

[33] Davis J A and Tgiuri (1982), "Bivalent Attributes of the Family Firm", Santa Barbara, CA, Owner Managed Business Institude.

[34] Dean Sylvia Melodyes (1992), "Characteristics of American Family-Owned Businesses in Los Angeles", Family Businesses Review, Vol.5,5no.4,pp.373-395

[35] Debicki Bart J (2009), "Family Business Research in the New Millennium”, Family Business Review, Vol.22, No.2, pp.151-166.

[36] Denoble Alex (2007). "Toward The Development of a Family Business Self-Efficiency scale", Family Business Review, Vol.20, PP.120-140

[37] Dess G (1987), "Consensus on Strategy Formulation and Organizational Performance, Competitors in a Fragmented Industry" $<$ Strategic Management Journal, Vol.8(3),pp.259-277.

[38] Dess G Robinson R (1984), "Measuring Organizational Performance In the Absence of Objective Measures, The Case of Privatelyheld Firm and Conglomerate Business Unit", Strategic Management Journal,Vol.5,pp.265-273.

[39] Dess G.G. and Robinson Jr. R B (1984), "measuring organizational performance in the Absence of Objective Measures, the Case of Privately-held firm and Conglomerate Unit", strategic Management journal, Vol.5, pp255-273.

[40] Dickinson T M (2000), "Critical Success Factors for Succession Planning in Family Business", University of Witwatersrand, Johannesburg. Cited in Adendroff, M (2005). The Development of a Cultural Family Business Model of Good Governance for Greek Family Business IN South Africa. PhD. thesis, Rhodes University.

[41] Distelberg Brain and Sorenson (2009), “Critical Systems Concepts in Family Business” ,Family Business Review, Vol.22,no.1,pp.65-81.

[42] Dreux D R (1990), "Financing Family Factor, The Impact of Family Relationship Dynamics on Business-Owning Families during Transitions", Family Business Review, Vol.12, no.1, pp.41-57.

[43] Dunn Barbara (1999), "The Family Factor, The Impact of Family Relationship Dynamics on Business-Owning Families during Transitions", Family Business Review, Vol.12, No.1, pp.41-57.

[44] Dyer Gibb and Dyer (2009), "Putting the Family Business Research", Family business Review, Vol.22, NO.3,PP.216-219.

[45] Dyer Jr W (2003), "The Family, The Missing Variable in Organizational Research", Entrepreneurship theory and practice, Vol.24 (4), pp.401-46.

[46] Dyer W G Jr and Sanchez M (1998), "Current State of Family Business Theory and Practice as Reflected in Family Business Review", Family Business Review, Vol.11(4),pp.14-18.

[47] Dyer W Gibb (2006), "Examining the Fmily Effect on Firm Performance", Family business Review, Vol.19,pp.253-273.

[48] Fiegener Mark K(1994), "A Comparison of Successor Development in Family and Non family Business", Family Business Review, Vol.7,No.4,pp.313-329.

[49] Galiano Alana M and Vinturella (1995), "Implications of Gender Bias in the Family Business", Family Business Review, Vol.8, No.3, PP.177-188.

[50] Gallo M A (1994), "Global Perspectives on Family Business", Chicago, Loyola university, Family Business Canter.

[51] Genusa A (1994), "Ergonomic Work Chairs Bring Family Success and challenges", Dallas Business Journal,Octomber,Vol7,pp.1420.

[52] Glick W H, Washburn N T and Miller C C (2005), "The Myth of Firm Performance", Paper Presented in the Annual Meeting of the Academy of Management, Honolulu, August 2005, as Coated in “A Critique of Measuring Post-acquisition Performance",(Athena Vasilaki IESEG, School of management, FRANCE).

[53] GLUECK w f and Meson T S (1980), “A Literature Analysis of Concepts”, Paper Presented at the Academy of Management Annual Meeting, Detroit, MI.

[54] Hall Annika and Nordqvist (2008), "Professional Management in Management in Family Business, Toward an Extended Understanding", Family Business Review, Vol.21, No, 1, pp.51-69.

[55] Handler W C (1989). "Methodology Issues and Consideration in Studying Family Businesses", Family Business Review, Vol.2, pp.257-276.

[56] Handler Wendy C. (1994), "Succession in Family Business, A Review of the Research", Family Business Review, Vol.7, No.2, pp.133-157.

[57] Harris Dawn and Ward (1994(, "Is Strategy Different for the Family-Owned Business", Family Business Review, Vol.7, No. 1, pp.3-16.

[58] Harvey Micheal and Evans (1995), "Life after Succession in the Family Business", Family Business Review, Vol.8, No.1, pp.3-16.

[59] Hollander B S and Elms N s (1988), "Family-Owned Businesses, An Engineering Field of Inquiry", Family Business Review, Vol.1, pp.145-164.

[60] Holt Daniel, T Rutherford AND Kuratko (2010), "Advancing the Field of Family Business Research, Further Testing the measurement Properties f the F-PEC", Family Business REVIEW, vol.23,No.1,pp.76-88.

[61] Hoy F (2003), "Legitimatizing Family Business in Organizational Research and Education", Entrepreneurship theory and Practice, Vol.27 (1), pp.117-122.

[62] Ibrahim A B and Ellis W H (1993), "Entrepreneurship and Small Business Management", Text, readings, and Cases, Dubuque, IA, Kendall/Hunt.Vol.14,pp.137-152.

[63] Jaffe D T (1990), "Working With Ones You Love Conflict Resolutions and Problems Solving Strategies for a Successful Business", Strategic Management Journal, Berkeley, CA.Vol.22,pp.817-844.

[64] Kowalewski Oskar, Talavera and Stets yak (2010)", "Inflame of Family Involvement in Management and Ownership on Firm Performance, Evidence From Poland", Family Business Review,Vol.23,No.1,pp.45-59.

[65] Lee Jean (2006), "Impact of Family Relationships on Attitudes of the Second Generation in Family Business", Family Business Review, Vol.19.No.3, pp.175-191.

[66] Littunen Hannu and Hyrsky (2000), "The Early Entrepreneurial Stage in Finnish and Non Family Firms", Family Business Review, Vol.13, no.1.pp.41-53.

[67] Longenecker J, Moore C and Schoeh J (1989), "Consumers Perceptions Of Family-Owned Service Industries, A Study of the "Family" cue in the Funeral Home Industry", Presented at the annual Meeting of the International Council on Small Business.

[68] Lorna Collins, Nicholas O'Regan, (2011),"Editorial: The evolving field of family business", Journal of Family Business Management, Vol. 1 Iss: 1 pp. 5 - 13

[69] Lyman A (1991), "Customer Services, Does Family Ownership Make a difference”, Family Business Review, Vol, 4, pp.303-324. 
[70] Maas G (1999), "Family Business in South Africa: A Development Model. Paper Presented at the Saesba Conference", Cited in Adendroff, M (2005). The Development of a Cultural Family Business Model of Good Governance for Greek Family Business in South Afarica PhD. Thesis, Rhodes University.

[71] Manikutty S (2000), "Family Business Groups in India, A_Resource-Based View of the Emerging Trends", Family Business Review, Vol.13, No.4, pp.279-292.

[72] Martinez J I (1994), "Family Business in Chile", Family Business network Newsltter, VOL.9.PP.5 -7.

[73] Massis Alfredo De, Chua Jess h and Chrisman James J (2008),'Factors Preventing INTRA Family Succession”, Family Business Review, Vol.no.21,pp.183-199.

[74] Mazzola Pietro and Marchisio (2002), "The Role of Going Public in Family Businnesses Long Lasting Growth: A Study of Italian IPOs", Family Business Review, vl.15 no.2,pp.133-148.

[75] Mazzola Pietro, Marchisio and Astrachan (2008), "Strategic in planning Family Business, A Powerful Development Tool for the Next Generation", Family Business review, Vol.21, no.3, pp.239-258.

[76] Mc Conughy, D Walker, M Henderson and G Mishra (1998), "Founding Family Controlled Firms, Efficiency and Value", Review Of Financial Economics, Vol.7, pp.1-19.

[77] Mosen R J (1969), “Ownership and Management, The Effect Of Separation on Performance”, Business Horizons, Vol,12,pp.46-52.

[78] Motwani Jaideep, Levenberg, Schwarz and Blankson (2006), "Succession Planning in SMEs", International Small Business Journal, Vol.24.No.5 pp.471-495.

[79] Nam Young-Ho and Herbert James I (1999), "Characteristics and Key Success Factors in Family Business", Family Business review, Vol.12.pp.314-356.

[80] Owens R (1994). “Australian Family Business, Ethics, Energy and Long Term Commitment; The Hallmarks of Success”, Family Business Network Newsletter, Vol.9, pp, 3-6.

[81] Paper, IM, II, as Coated in "A Critique of measuring Post-acquisition Performance", (Athina vasilaki IESEG, School of management, France).

[82] Powell T C (1992), “Organizational Alignment as Competitive Advantages”, Strategic Management Journal,Vol.13(7),pp.551-558.

[83] Powell T C Dent-Micallef A (1997), "Information Technology as Competitive Advantages, the Role of Human, Business and Technology Resources", Strategic Management Journal, Vol.18 (5), pp.375-405.

[84] Poza Ernesto J (2010), "Family Business" Monson OH, USA, South-Western Cengage Learning, $3{ }^{\text {rd }}$ Edition.

[85] Poza Ernesto J, Alfred and Masheshwari (1997), "Stakeholder perceptions of Cultural and Management Practices in Family and Family Firms", Family Business Review, Vol, 10, No.2.pp.135-155.

[86] Prokesch S (1986), "Renewing Traditional Values, When the Relatives Fall Out, Wresting With Vulnerability", New York Times, June 10 .

[87] Reidel H (1994), "Family Business in Germany", Family Business Network Newsletter, Vol.9,p.6.

[88] Rouvinez Denise Kenyon (2001), "Patterns in Serial Business Families, Theory Building through Global Case Study Research", Family Business Review, Vol, 14.No, 3, pp.175-191.

[89] Royer Susanne, Simons, Boyd and Raffesty (2008), "Promoting Family, A Contingency Model of Family Business Succession", Family Business Review, Vol.21, No.1.pp.15-30.

[90] Rutten Mario (2001), "Family Enterprises and Business Partnerships, Rural Entrepreneurs in India, Malaysia, and Indonesia", Journal of Entrepreneurship, Vol.10.no.2, pp.165-189.

[91] Santago Andrea 1 (2000), "Succession Experience in Philippine Family business", Family Business Review, Vol.13.No.1.pp.15-35.

[92] Sapienza H J, Smith KG and Cannon M J (1988), "Using Subjective Evaluations of Organizational Performance in Small Business Research", American Journal of Small Business, Vol.12, pp.45-53.

[93] Sciascia Salvatore and Mazola Pietro (2008), "Family Involvement in Ownership and Management", Family Business Review, Vol, 21.pp.331-345.

[94] Sexton D and Bowman-Upton N (1991), "Entrepreneurship, Creativity and Growth", New York, MacMillan Publishing. Vol.18.pp.123-145.

[95] Shafrman M P and Dean Jr J W (1991), "Conceptualizing and Measuring the Organizational Environment, A Multidimensional Approach”, Journal of Management, Vol,7,pp.681-700.

[96] Shapero A and Sokol L(1982), “The Social Dimensions of Entrepreneurship", In C Kent, D Sexton, and K Vesper (EDs.) Encyclopedia of Entrepreneurship (pp. 72-90). Englewood Cliffs, NJ: Prentice-Hall.Vol.23,pp.34-56.

[97] Sharma P, Chrisman J J and Chua J H (1996), "A Review nd Annotated Bibliography of Family Business Studies", Boston, MA, Kluwer Academic Publishers. Family Business Review, Vol.13.PP.11-16.

[98] Sharma P, Chrismas J J and Chua J H (1996), “A Review and Annotated Bibliography of Family Business Studies”, Boston, M A, Kluwer Academic Publishers. Family Business Review, Vol.13.pp.11-16.

[99] Sharma Pramodita (2004_, "An Overview of the Field of Family Business Studies, Current Status and Direction for the Future", Family Business Review, Vol.1,No1,pp.104-106.

[100] Sharma Pramodita and Rao (2000), "Successor Attributes in India and Canadian Family Firms, A Comparative Study", Family Business Review, Vol.17,No,1,PP.104-106.

[101] Sharma Pramodita, Chrismas James J and Chua Jess H (2003), "Succession Planning as Planned Behavior", Family Business Review, Vol.16,pp.1-16.

[102] Song M, Droge C, Hanvanich S and Calantone R (2005), "Marketing and Technology Resource Complementarily, an Analysis of Their Interaction Effect in two Environmental Contexts", Strategic Management Journal, Vol.26.pp.259-276.

[103] Sorensn Ritch L, Goodpaster, Edberg and Andy (2009), "The Family Point of View, Family Social Capital, and Firm Performance", Family Business Review, Vol,22.No.3,pp.239-253.

[104] Stavrou Eleni T (1998), "Four Factor Model, A Guide to Planning Next Generation Involvement in the Family Firm", Family Business Review, Vol.11, No.2, pp.135-142.

[105] Steier Lioyd (2001), "Next-Generation Entrepreneurs and Succession", Family Business Review, Vol.14,pp.259-276.

[106] Sundaramurthy Chamu (2008), "Sustaining Trust Within Family Business, "Family Business Review Vol.21,No.1,pp.89-102.

[107] Tan Wee-Liang and Fock (2001), "Coping With Growth Transition, The Case of Chinese Family Businesses in Singapore", Family Business Review, Vol, 14, No.2, pp.123-139.

[108] Tatoglu Ekrem Kula and Glaister (2008), "Succession Planning in Family-Owned, Vol.26, N.2, pp.155-180.

[109] Timmons J A and Spinelli S (2007), "New Venture Creation. Entrepreneurship in the 2ist Century" $7^{\text {th }}$ edition. McgrawHill.Vol.11, pp.321-345.

[110] Tippins M J Sohi RS (2003), "IT Competency and Firm Performance, is Organizational Learning a Missing Link", Strategic Management Journal, Vol.24, pp.745-761. 
[111] Veliyath Rajaram and Raamanswamy (2000), "Social Embeddings, Overt and Covert Power, and their Effects on CEO Pay, An Empirical Examination Among Family Businesses in India”, Family Business Review, Vol.13,No,4.pp.293-311.

[112] Venter E (2002), "The Succession Process in Small and Medium-Sized Family Business in South Africa", University of Port Elizabeth. Cited in Adendroff, M. (2005). The Development of a Cultural Family Business Model of Good Governance for Greek Family Business in South Africa. PHD. Thesis, Rhodes University Enterprise.

[113] Venter E Boshoff and Maas (2006), "The Influence of Successor-Related Factors $n$ the Succession Process in Small and MediumSized Family Business", Family Business Review, Vol.18,No.4,pp.283-303.

[114] Vinturella J, Elstrott J B and Galiano A (1993). "University Programs For Family Business, Survey and Projection”, In Directors MANUAL, International Family Business Program Association. VOL.31,PP.34-77.

[115] Ward J L (1987), "Keeping the Family Business Healthy: How to Plan for Continuing Growth, Profitability, and Family Leadership", San Francisco, CA, Jossey-BASS. Vol.23,pp.65-77.

[116] Wethead Pual and Howorth Carol (2006), "OWNERSHIP AND Management Issues Associated With Family Firm Performance AND Company”, Family Business Review 2006, Vol.19, pp.301-316. 